\title{
Indicative value of different taxonomic levels of Chironomidae for assessing the water quality
}

\author{
Carlos Molineria,*, Eva G. Tejerina $^{\mathrm{a}}$, Silvia E. Torrejón ${ }^{\mathrm{b}}$, Edgardo J.I. Pero ${ }^{\mathrm{a}}$, Guillermo E. Hankel ${ }^{\mathrm{a}}$ \\ ${ }^{a}$ Instituto de Biodiversidad Neotropical, CONICET-Universidad Nacional de Tucumán, Facultad de Ciencias Naturales, Ciudad Universitaria, Horco Molle, 4105 Tucumán, \\ Argentina \\ ${ }^{\mathrm{b}}$ Instituto de Ecorregiones Andinas, Universidad Nacional de Jujuy - CONICET, Argentina
}

\section{A R T I C L E I N F O}

\section{Keywords:}

ROC curves

Midges

Water-quality

Chironominae

Orthocladiinae

Tanypodinae

\begin{abstract}
A B S T R A C T
Most biological indices of pollution treat Chironomidae (Diptera) as a bad quality indicator, but under certain natural circumstances (e.g., frequent disturbs, dominance of fine sediments) this group forms almost the entire freshwater community. Metrics are needed to evaluate pollution under such circumstances, thus we tested the efficiency of Chironomidae larvae at morpho-species, subfamily and family levels, to detect a variety of human impacts on rivers. We used 75 samples (25 sampling stations, each with three replicates) and environmental data from mountain rivers (7 impacted and 18 non-polluted) from NW Argentina. Thirty (30) morpho-species in four subfamilies occurred in the studied sites. ROC (Receiving Operating Characteristic) curves were used to assess the efficiency of these taxa as indicators of water quality, and to propose thresholds separating both environmental groups (polluted/non-polluted). The number of morpho-species per subfamily or family proved to be a powerful discriminator between polluted and non-polluted sites. Various metrics are developed here based on richness and density of Chironomidae at different taxonomical levels. Non-polluted sites are predicted to present more than 6 morpho-species of Chironomidae, or at least 3 of Orthocladiinae, or 3 Chironominae, or 1 Tanypodinae. On the contrary, the presence of Chironomus gr. decorus indicated pollution.
\end{abstract}

\section{Introduction}

Biotic indices based on macroinvertebrates are widely used to assess stream health (Bonada et al., 2006; Carter et al., 2017), data input of the entire community at different taxonomic levels (generally family or species) is required by most of them. Aquatic communities are dynamic in their composition and densities, depending on spatial and temporal environmental variations (Heino et al., 2015). Chironomidae are responsible of most of the richness and abundance of aquatic communities, especially in naturally poor environments (Serra et al., 2017), and are generally considered a pollution resistant group (e.g., Armitage et al., 1983; Jacobsen, 1998; Fernández et al., 2006). In biomonitoring, a rather impoverished benthic community dominated by this family, is generally attributed to bad water quality (Saether, 1979; Raunio et al., 2007).

Contrariwise, many works found that selected groups inside the family (subfamilies, genera, and species) are indicators of good water quality (Lenat, 1993; Paggi, 1999, 2003; Marques et al., 1999; Lencioni et al., 2012). It has been shown that under certain natural circumstances such as frequent disturbs, dominance of fine sediments, or generally harsh environments (Lenat, 1983; Jacobsen, 1998; Puntí et al., 2009; Lencioni et al., 2012) almost the entire freshwater community is composed by Chironomidae. The need to evaluate pollution under such circumstances collides with the lack of data at different taxonomic levels in this taxon. In spite of the growing need of biomonitoring tools, few studies have paid attention to Chironomidae at a fine identification level (but see Serra et al., 2017).

Most biological metrics and sensitivity values using Chironomidae are drawn from subjective or indirect sources, mainly the valorization by experts (Armitage et al., 1983; Hilsenhoff, 1988). But objective treatment of the data of the family (or intrafamily groups) in rivers with varied condition, and with the aim of checking for their suitability as indicators, is rare (Puntí et al., 2009; Dos Santos et al., 2011; Lencioni et al., 2012).

ROC curves (Receiving Operating Characteristic) present important advantages to evaluate biological metrics used as ecosystem health tests, and have demonstrated its proficiency in detecting good indicators from a pool of many possible biological metrics (Lasko et al., 2005; Dos Santos et al., 2011). ROC curves evaluate metric performance directly, when the actual water quality ("gold standard") is known from

\footnotetext{
* Corresponding author.

E-mail address: carlosmolineri@gmail.com (C. Molineri).
} 

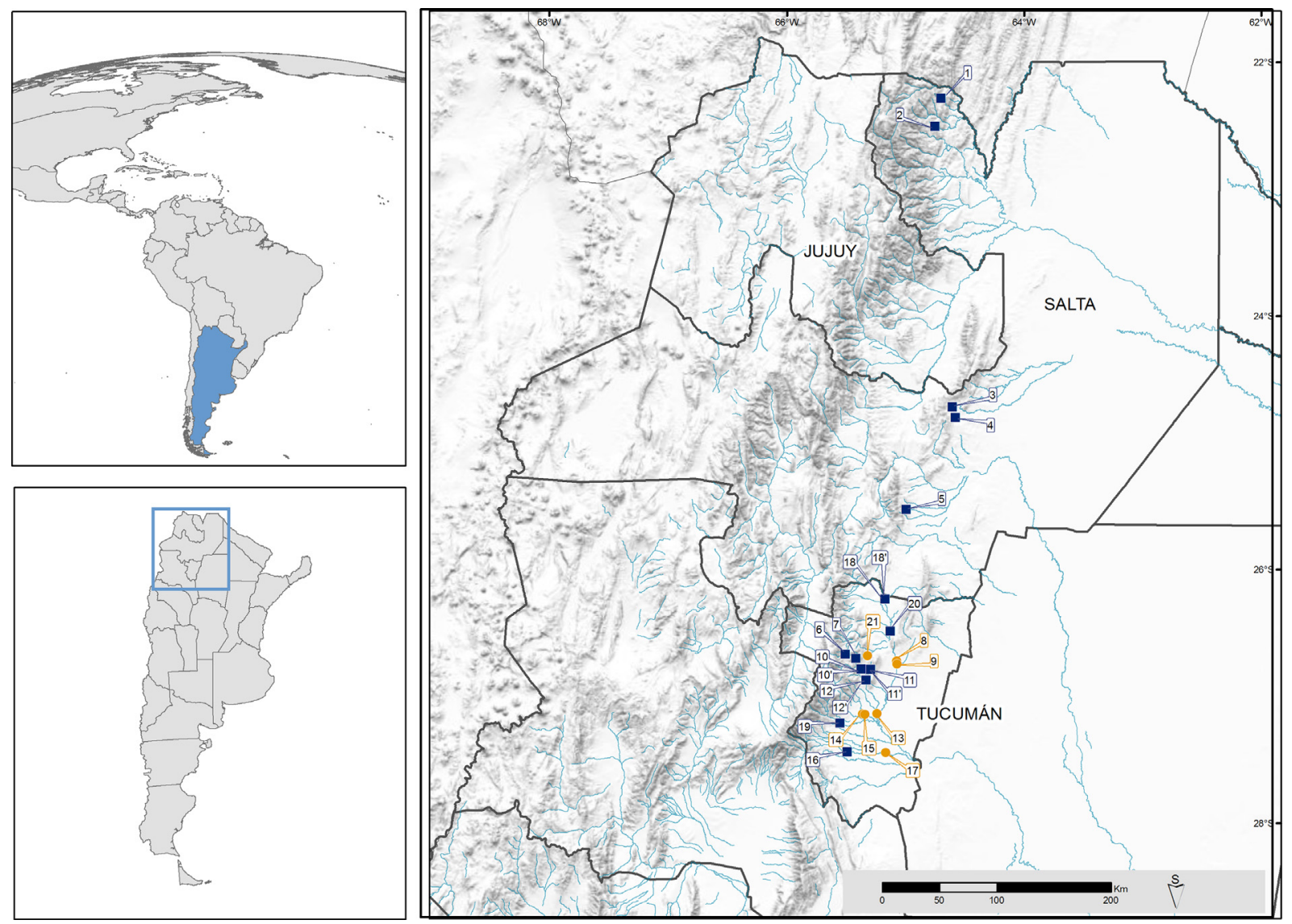

Fig. 1. Map of study region. Squares $=$ non-polluted sites, circles $=$ polluted sites. See site number references in Table 1 .

Table 1

Sampling site characterization.

\begin{tabular}{|c|c|c|c|c|c|c|c|c|c|c|c|}
\hline Site code/impact ${ }^{1}$ & Site & Impacts $^{2}$ & Latitude & Longitude & Alt $(m)^{3}$ & Substrate $^{4}(\mathrm{~mm})$ & $\mathrm{CE}(\mu \mathrm{S} / \mathrm{cm})^{5}$ & Width (m) & Depth (m) & $\operatorname{Vel}(\mathrm{m} / \mathrm{s})^{6}$ & $\mathrm{pH}$ \\
\hline $1 / \mathrm{NP}$ & Huaico Grande & $\mathrm{D}$ & -22.27889 & -64.71083 & 1645 & 200 & - & 5 & 0.3 & - & - \\
\hline $2 / \mathrm{NP}$ & Baritú & $\mathrm{D}, \mathrm{Ct}$ & -22.49944 & -64.76583 & 1481 & 160 & - & 5 & 0.2 & - & - \\
\hline $3 / \mathrm{NP}$ & San Roberto & - & -24.71611 & -64.64556 & 1050 & 130 & 597 & 2 & 0.1 & - & 7 \\
\hline $4 / \mathrm{NP}$ & Los Noques & - & -24.79778 & -64.62083 & 965 & 130 & 105 & 2 & 0.15 & - & 6.5 \\
\hline $5 / \mathrm{NP}$ & Palo Largo & Lo & -25.51778 & -65.05542 & 1030 & 155 & - & 4 & 0.15 & - & - \\
\hline 6/NP & Liquimayo & $\mathrm{Ct}$ & -26.65103 & -65.61147 & 2170 & 340 & 57 & 8.8 & 0.13 & 0.7 & 7 \\
\hline $7 / \mathrm{NP}$ & San Miguel & - & -26.68547 & -65.51942 & 1300 & 210 & 166 & 1.4 & 0.07 & 0.1 & 8 \\
\hline $10 / \mathrm{NP}$ & Las Juntas & $\mathrm{Ch}, \mathrm{Ct}$ & -26.76944 & -65.47233 & 925 & 170 & 135 & 12.7 & 0.37 & 0.8 & 8 \\
\hline $10^{\prime} / \mathrm{NP}$ & Las Juntas & $\mathrm{Ch}, \mathrm{Ct}$ & -26.76944 & -65.47233 & 925 & 170 & 129 & 13.4 & 0.43 & 1.1 & 6 \\
\hline $11 / \mathrm{NP}$ & San Javier & $\mathrm{Ct}, \mathrm{Cp}$ & -26.77394 & -65.38994 & 860 & 120 & 373 & 4.1 & 0.12 & 0.7 & 8 \\
\hline $11^{\prime} / \mathrm{NP}$ & San Javier & $\mathrm{Ct}, \mathrm{Cp}$ & -26.77394 & -65.38994 & 860 & 120 & 270 & 4.2 & 0.13 & 0.6 & 6 \\
\hline $12 / \mathrm{NP}$ & Potrero & $\mathrm{D}, \mathrm{Ct}$ & -26.85522 & -65.43208 & 680 & 105 & 657 & 11.1 & 0.24 & 0.8 & 9 \\
\hline $12^{\prime} / \mathrm{NP}$ & Potrero & $\mathrm{D}, \mathrm{Ct}$ & -26.85522 & -65.43208 & 680 & 105 & 569 & 5.8 & 0.25 & 0.6 & 8 \\
\hline $16 / \mathrm{NP}$ & Medina & Ch, D & -27.42094 & -65.61147 & 363 & 5 & 236 & 12 & 0.5 & 1 & 8.4 \\
\hline $18 / \mathrm{NP}$ & Boyero & $\mathrm{Ct}, \mathrm{D}$ & -26.22194 & -65.25417 & 761 & 50 & 741 & 11 & 0.22 & 1.3 & 8.39 \\
\hline $18^{\prime} / \mathrm{NP}$ & Boyero & $\mathrm{Ct}, \mathrm{D}$ & -26.22194 & -65.25417 & 761 & 50 & 715 & 10.7 & 0.24 & 0.5 & 7 \\
\hline $19 / \mathrm{NP}$ & Pueblo Viejo & $\mathrm{Ch}$ & -27.19139 & -65.67000 & 543 & 90 & 112 & 23 & 0.14 & 0.5 & 8.8 \\
\hline $20 / \mathrm{NP}$ & San Vicente & Ct, D & -26.47589 & -65.21206 & 649 & 35 & 989 & 21.4 & 0.20 & 0.5 & 7 \\
\hline $21 / \mathrm{P}$ & Yerba Buenita & $\mathrm{Ct}, \mathrm{D}, \mathrm{Ws}$ & -26.66583 & -65.41389 & 950 & 140 & 1250 & 1.5 & 0.1 & 0.4 & 7.7 \\
\hline $13 / \mathrm{P}$ & Colorado & Lo, Ch, Ct, Cp, Ws & -27.12297 & -65.34222 & 337 & 85 & 917 & 20 & 0.5 & 0.7 & 7.4 \\
\hline $14 / \mathrm{P}$ & Hollinado A & Lo, Ch, Cp & -27.12389 & -65.46917 & 355 & $<3$ & 241 & 1.5 & 1 & - & 7.3 \\
\hline $15 / \mathrm{P}$ & Hollinado B & Lo, Ch, Cp, Ws & -27.12639 & -65.44833 & 352 & $<3$ & 447 & 2 & 0.5 & - & 7.4 \\
\hline $17 / \mathrm{P}$ & Gastona & Lo, Ch, Cp, Ws & -27.43255 & -65.27185 & 298 & $<3$ & 373 & 35 & 1 & 0.7 & 6.9 \\
\hline $8 / \mathrm{P}$ & Sali A & Lo, Ch, D, Cp & -26.71194 & -65.15944 & 482 & $<3$ & 970 & 15 & 0.4 & - & 7.8 \\
\hline $9 / \mathrm{P}$ & Sali B & Lo, Ch, D, Cp, Ws & -26.73611 & -65.15833 & 470 & $<3$ & 1113 & 16 & 0.4 & - & 8.2 \\
\hline
\end{tabular}

$1 \mathrm{NP}=$ non-polluted, $\mathrm{P}=$ polluted.

${ }^{2}$ Lo $=$ logging, $\mathrm{Ch}=$ channel modification, $\mathrm{D}=$ domestic/recreational use, $\mathrm{Ct}=$ cattle, Ws $=$ waste water, $\mathrm{Cp}=$ crops.

3 Altitude.

4 Mean particle size.

5 Conductivity.

6 Mean water velocity. 


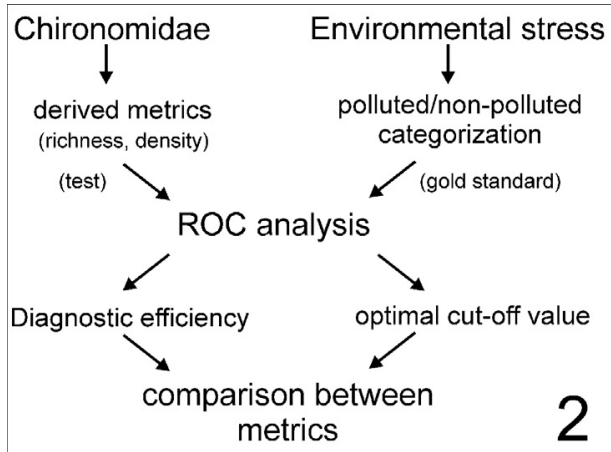

Fig. 2. Schematic diagram showing the logic of analysis.
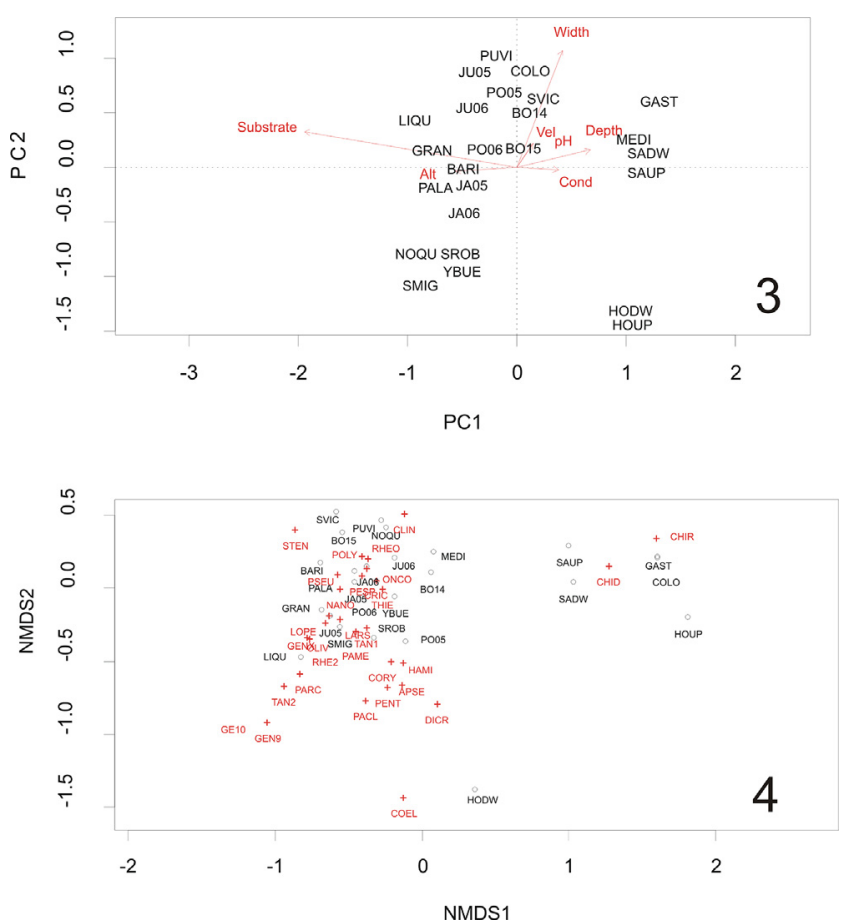

Figs. 3-4. Multivariate ordinations: 3, PCA axes 1 and 2 showing the ordination of 25 sites from 7 physico-chemical variables; 4, NMDS axes 1 and 2 showing the ordinations of 25 sites from 30 taxa. Site abbreviations: Huaico Grande (GRAN), Baritú (BARI), San Roberto (SROB), Los Noques (NOQU), Palo Largo (PALA), Liquimayo (LIQU), San Miguel (SMIG), Las Juntas05 (JU05), Las Juntas06 (JU06), Potrero 2005 (PO05), Potrero 2006 (PO06), Medina (MEDI), Boyero 2014 (BO14), Boyero 2015 (BO15), Pueblo Viejo (PUVI), San Vicente (SVIC), Yerba Buenita (YBUE), Colorado (COLO), Hollinado up (HOUP), Hollinado down (HODW), Gastona (GAST), Salí up (SAUP), Salí down (SADW). See Appendix 1 for taxon abbreviations.

independent sources (e.g., physical-chemical analysis), providing threshold values for those metrics that separate polluted from nonpolluted sites.

We use data from NW Argentina, mainly the Salí-Dulce river basin, the second most polluted basin in this Country (Domínguez and Fernández, 1998), affected by concentrated industrial activities (related to sugar cane and lemon) and domestic wastewaters. Paradoxically, the basin also drains a large surface of mountain rain forest (Yungas) with high conservancy value. The information generated in this study is also relevant for other mountain regions with landscape patches of natural and productive areas. The aim of this work is to assess the efficiency of different taxonomic levels of Chironomidae (morpho-species, subfamily and family) as indicators of water quality through the ROC curves methodology. Dos Santos et al. (2011) used this methodology to evaluate biological metrics in the area, at different scale of analysis (broader, many basins), different sites and samples (95 sites), and different focal group (the entire benthic community). Specifically we want to: 1) compare the diagnostic ability of the family and subfamilies using richness (morpho-species level) data, 2) the same but using abundance data at morpho-species level; and 3) identify the cut-off values (at all these taxonomic levels) separating polluted from non-polluted sites.

\section{Material and methods}

\subsection{Study sites}

Twenty five sampling sites from 20 rivers were studied (Fig. 1), most of them included in the Yungas ecoregion, a subtropical rain forest with monsoon climate (Mendoza and González, 2011). The sites were assigned to 2 categories, polluted and non-polluted, respectively (Table 1), according to the importance and number of human-impacts affecting them (see below for further explanations). Samples were taken in sites with high slope and coarse substrate, surrounded by natural vegetation except five in productive areas with highly modified marginal vegetation, lower slopes and fine substrate (Table 1). Each category (polluted/non-polluted) is represented by both kinds of sites, with the aim of reducing possible bias related to these natural environmental gradients (e.g., altitude, stream size, substrate, slope).

Samples were taken in the dry season (September-November), where discharge attains the lowest values, in different years (2003-2015), and using three replicates of Surber samples $(300 \mu \mathrm{m}$ pore size, $0.09 \mathrm{~m}^{2}$ of sampled area) in most sites, or 3 replicates of artificial substrates $(10 \times 15 \mathrm{~cm}$ bags $10 \mathrm{~mm}$ mesh-size filled with small stones $<50 \mathrm{~mm}, 15$ colonization days) in four sites (sites $8-9$ and 14-15, Table 1). We used artificial stony substrates ( 3 bags per site) in those sites because they were dominated by fine sediments, stony patches being not frequent enough to take Surber samples on them. When processing the material inside each bag, $300 \mu \mathrm{m}$ pore size sieves were used. To avoid non-desired influences on the results (due to different sampling methods in these few sites), density of larvae from the artificial substrates was calculated from the total surface of the stones, thus the unit of comparison between both samplers is the same (individuals/ area). High water periods were avoided because dilution decrease the possibility to detect impacts and macroinvertebrate communities are naturally impoverished by spates (Domínguez and Fernández, 1998; Fernández et al., 2006).

\subsection{Data analysis}

General community and physico-chemical patterns were analyzed with multivariate ordinations. Relationships between biological data, an incidence matrix of 30 taxa $\times 25$ sites, transformed by natural logarithm LN $(x+1)$ to homogenize the variance, were analyzed with NMDS (non-metric multidimensional scaling, Kenkel and Orlóci, 1986). A matrix of 25 sites and 7 physico-chemical variables was analyzed with a PCA (principal component analysis, Kenkel and Orlóci, 1986); variables were standardized by means of $\mathrm{LN}(\mathrm{x})$, except $\mathrm{pH}$. All analyses were conducted in R, version 3.5.1 (R Core Team, 2018), employing the package vegan (Oksanen et al., 2018).

\subsection{Efficiency calculation}

ROC (Receiving Operating Characteristics) curves analysis is a useful tool with multiple advantages but scarcely used in the field of bioindication (Dos Santos et al., 2011). This methodology can be used to compare the efficiency of a metric (e.g., a pollution index, the presence or diversity of a taxon, etc.), to identify thresholds of decision (cut values) for those indices and to analyze the response of different indices to increasing levels of disturbance (Dos Santos et al., 2011). ROC analyses were performed in R (R Core Team, 2018), with the package pROC 

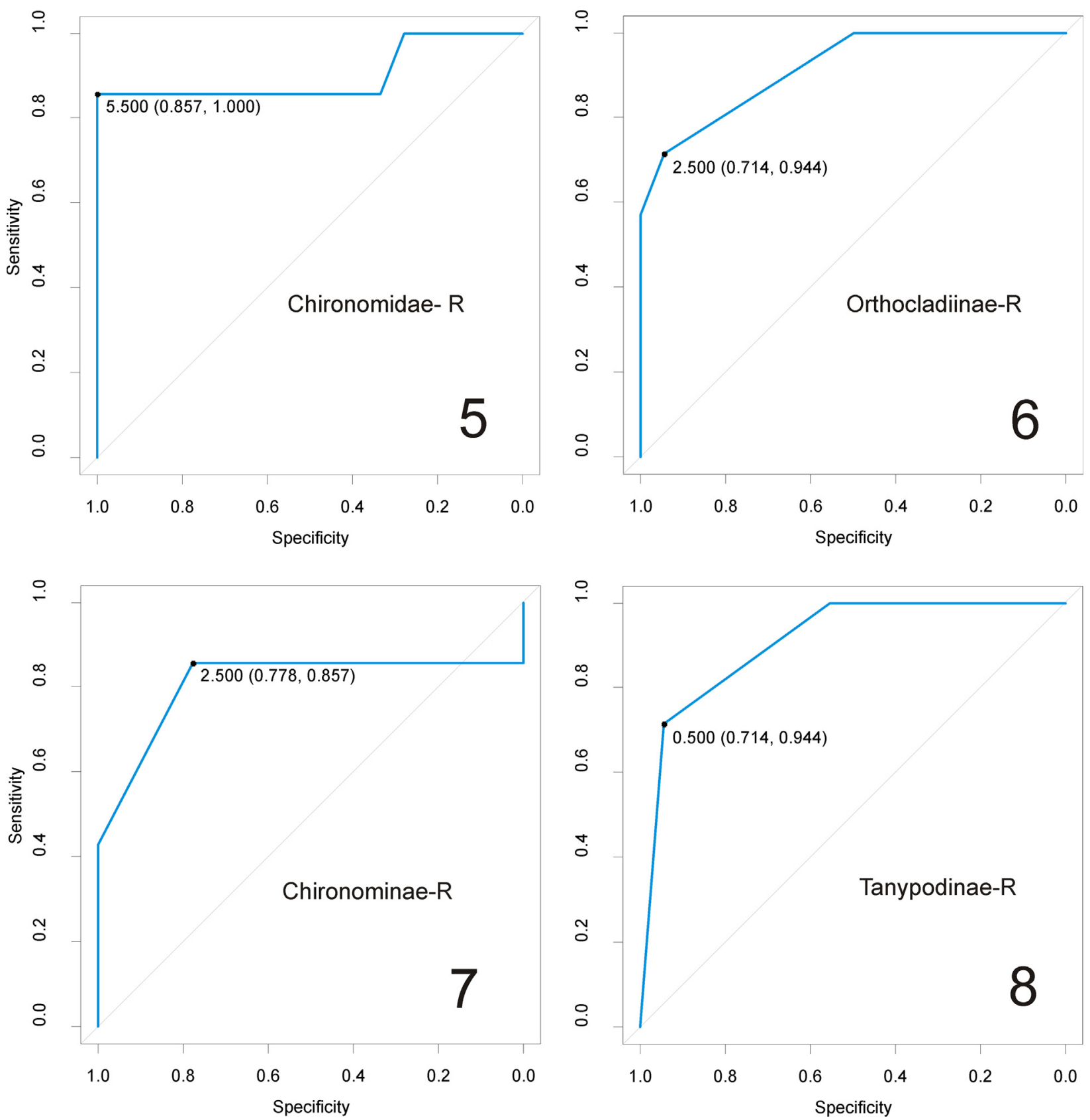

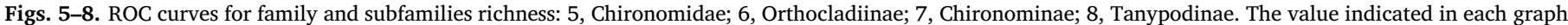

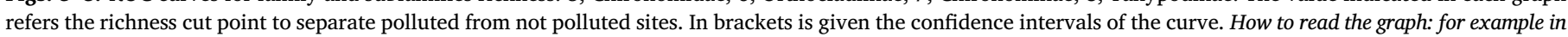

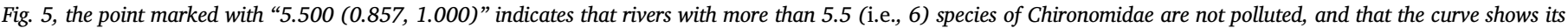
lower CI level at 0.857 AUC (area under de curve) and the upper at 1.000 AUC.

(Robin et al., 2011), following the procedure described in Dos Santos et al. (2011). The logic of the analysis can be seen in Fig. 2. The "gold standard" (actual disturbance status of each site: polluted or not) was determined from the number of polluting activities in the immediate upper basin (fixed buffer $5 \mathrm{~km}$ ) and on the margins (fixed width $100 \mathrm{~m}$ ), including the following categories: crops, cattle, industrial or city waste-waters, physical modification of the riverbed or margins, severe degradation of marginal vegetation, and recreational uses (Table 1). Sites affected by waste water discharge or at least by three of the other impacts simultaneously, were classified as "polluted", threshold found by a previous study in the region (Dos Santos et al., 2011). This classification was corroborated with environmental data obtained at the same time of biological sampling (Table 1) and from published reports on DO (dissolved oxygen), BOD (biological oxygen demand) and nutrients (Domínguez and Fernández, 1998; Fernández et al., 2006) for some of the sites. Sites not affected by effluents and with 2 or less of the other impacts were included in the "non-polluted" group (Table 1).

We used two kinds of metrics to perform ROC analyses: 1) species abundance from an incidence matrix, and 2) richness values (number of morpho-species per family/subfamily). Thus we obtained to kinds of cut-off values to recognize polluted sites: 1 ) the density of larvae, and 2) the number of morpho-species from each family/subfamily group.

\section{Results}

Multivariate ordination of sites by environmental variables (PCA, Fig. 3) shows sampling stations at lower altitude, finer sediment, higher conductivity and depth (Table 1 ) toward the positive side of axis 1 (axis 
Table 2

Results from ROC analyses.

\begin{tabular}{|c|c|c|c|}
\hline & $\mathrm{AUC}^{1}$ & $95 \% \mathrm{CI}^{2}$ & Cut value $^{3}$ \\
\hline Chironomidae (richness) & 0.90 & $0.72-1.00$ & $\geq 6 \mathrm{spp}$ \\
\hline Diamesiinae (Paraheptagyia sp.) & 0.36 & $0.25-0.47$ & - \\
\hline Tanypodinae (richness) & 0.91 & $0.80-1.00$ & $\geq 1 \mathrm{spp}$ \\
\hline Pentaneura sp. & 0.81 & $0.54-1.0$ & 0.2 ind/surber \\
\hline Pentaneurini 1 & 0.42 & $0.33-0.51$ & - \\
\hline Coelotanypus & 0.50 & $0.32-0.68$ & - \\
\hline Larsia sp. & 0.42 & $0.33-0.512$ & - \\
\hline Apsectrotanypus sp. & 0.44 & $0.37-0.52$ & - \\
\hline Clinotanypus & 0.42 & $0.33-0.505$ & - \\
\hline Orthocladiinae (richness) & 0.92 & $0.80-1.00$ & $\geq 3$ spp \\
\hline Genus 9 & 0.47 & $0.42-0.53$ & - \\
\hline Genus 10 & 0.47 & $0.42-0.53$ & - \\
\hline Corynoneura sp. & 0.62 & $0.37-0.86$ & - \\
\hline Onconeura sp. & 0.89 & $0.72-1.00$ & $0.4 \mathrm{ind} /$ surber \\
\hline Thienemanniella sp. & 0.76 & $0.57-0.94$ & $0.5 \mathrm{ind} /$ surber \\
\hline Oliveiriella sanjavieri & 0.78 & $0.66-0.90$ & 0.9 ind/surber \\
\hline Cricotopus sp. & 0.85 & $0.65-1.00$ & $17.0 \mathrm{ind} /$ surber \\
\hline Genus $X$ & 0.47 & $0.42-0.53$ & - \\
\hline Nanocladius sp. & 0.32 & $0.16-0.47$ & - \\
\hline Lopescladius sp. & 0.28 & $0.16-0.40$ & - \\
\hline Paracladius? & 0.44 & $0.37-0.52$ & - \\
\hline Parametriocnemus sp. & 0.69 & $0.49-0.90$ & $0.9 \mathrm{ind} /$ surber \\
\hline Chironominae (richness) & 0.82 & $0.55-1.00$ & $\geq 3 \mathrm{spp}$ \\
\hline Pseudochironomus sp. & 0.72 & $0.48-0.96$ & 0.2 ind/surber \\
\hline Tanytarsus sp 1 & 0.73 & $0.48-0.98$ & $0.2 \mathrm{ind} /$ surber \\
\hline Tanytarsus sp 2 & 0.42 & $0.33-0.51$ & - \\
\hline Rheotanytarsus lamellatus & 0.79 & $0.52-1.00$ & $0.7 \mathrm{ind} /$ surber \\
\hline Rheotanytarsus sp. 2 & 0.42 & $0.33-0.51$ & - \\
\hline Polypedilum sp. & 0.87 & $0.71-1.00$ & $0.5 \mathrm{ind} /$ surber \\
\hline Complejo Harnischia & 0.49 & $0.32-0.66$ & - \\
\hline Chironomus sp. & 0.64 & $0.46-0.82$ & - \\
\hline Chironomus gr decorus & 0.84 & $0.66-1.00$ & $2.5 \mathrm{ind} /$ surber* \\
\hline Dicrotendipes sp. & 0.60 & $0.39-0.80$ & - \\
\hline Stenochironomus sp. & 0.47 & $0.42-0.53$ & - \\
\hline
\end{tabular}

1 AUC $=$ area under the ROC curve.

$2 \mathrm{CI}=$ confidence interval.

${ }^{3}$ Cut value $=$ values above the given number indicate healthy sites.

* This taxon indicates bad quality.

1 explains $56 \%$ of variance). Mountain sites are towards the negative side of this axis. On the second axis ( $16 \%$ of variance), the channel width is important, separating smaller streams at the negative side while rivers are on the positive side (Fig. 3). Polluted and non-polluted sites appear mixed in the ordination.

The ordination of sites by biological data (NMDS, stress 0.11 ; Appendix 1) can be seen in Fig. 4: five sites are clearly separated toward the positive side of axis 1 (Salí up, Salí down, Colorado, Gastona and Hollinado up) with a high contribution of Chironomus sp. and Chironomus gr. decorus. Hollinado down is in an intermediate position between this group of sites and all the rest, but Hollinado down appears in the negative side of axis 2 . All the remaining sites form a more tightly ordered group (Fig. 4).

A total of 13,367 larvae of Chironomidae were sorted and identified, densities ranged from 56 ind $/ \mathrm{m}^{2}$ (in the highly impacted Hollinado B stream) to 29,861 ind $/ \mathrm{m}^{2}$ (in Potrero de las Tablas 2005, a moderately nutrient-enriched river). Diamesiinae only was recorded in five sites at low densities (4-385 ind $/ \mathrm{m}^{2}$ ). With varying densities (3-3372 ind $/ \mathrm{m}^{2}$ ), Tanypodinae were collected in 19 sites. Orthocladiinae were only absent in three of the most polluted sites (Colorado, Hollinado B, Gastona). Orthocladiinae presented a minimum of 44 and a maximum of $9489 \mathrm{ind} / \mathrm{m}^{2}$; the lower values coincided with heavily impacted sites (Table 1, Appendix 1). Finally Chironominae were present in all the sites generally with high densities (33-17000 ind $/ \mathrm{m}^{2}$ ).

Diamesiinae and Tanypodinae were absent from the six most polluted sites, with the exception of Coelotanypus sp. (Tanypodinae) present in Hollinado A stream (Appendix 1). Orthocladiinae were absent or reached very low densities (44-167 ind $/ \mathrm{m}^{2}$ ) in this group of sites, with only 1-3 contributing genera. On the contrary, Chironominae presented relatively high densities in these sites, with Chironomus decorus group as the most important contributor (Appendix 1).

\subsection{ROC curves (Table 2, Figs. 5-12)}

Morpho-species richness was an efficient indicator, for example the presence of at least 6 morpho-species of Chironomidae is an excellent indication of good water quality (Fig. 5); and at the subfamily level, the presence of 3 morpho-species of Orthocladiinae (Fig. 6), or Chironominae (Fig. 7) are also excellent indicators of good water quality. The presence of Tanypodinae resulted in a good test of water quality (Table 2, Fig. 8). But polluted and non-polluted sites were not differentiated by the presence of the family Chironomidae (i.e., identified to that level only) or the subfamilies Orthocladiinae and Chironominae.

Analyses using taxon-densities also showed interesting results. Ten morpho-species were found to be efficient indicators of good water quality and one indicated polluted sites (Table 2).

Chironomus decorus group resulted a very good indicator of bad water quality (Fig. 9), since it is common in polluted sites (being the only Chironomidae present or occurring with other species), but it is absent from non-polluted sites. Examples of good water indicators can be seen in Figs. 10 and 12, and a non-informative taxon on Fig. 11.

\section{Discussion}

Morpho-species richness found in this work is similar to that reported in other studies based on larvae in the region, ranging from 15 to 31 genera (Tejerina and Malizia, 2011; Príncipe et al., 2008). Publications relating Chironomidae with bioindication are scarce in the studied region (Nicacio and Juen, 2015).

The high values of the AUCs ("area under the curve" approximating 1, i.e. perfect efficacy to discriminate polluted from not polluted sites) for Chironomidae at different taxonomic levels prove them to be a good indicator to evaluate water quality in rivers. The long standing idea of the family as indicator of bad water quality (Armitage et al., 1983; Hilsenhoff, 1988) or even as not useful in biomonitoring (Rabeni and Wang, 2001) was criticized by many authors, who defended some intrafamilial groups as indicators of preserved ecosystems (e.g., Marques et al., 1999). Our results are in accordance with both views, the presence of Chironomidae (at the family level) cannot be used to discriminate polluted from non-polluted sites, but its richness or the presences of selected groups are excellent indicators. Furthermore, opposite scenarios are readily distinguished: non-polluted (some individual genera, the subfamily Tanypodinae) and polluted (Chironomus decorus group).

It was unexpected to us that one taxon (Chironomus decorus group) was a very good indicator of polluted sites. Most interpretations of biological indices are drawn from the reduction of an original pool, including tolerant and sensitive species (in non-polluted sites), to an assemblage of only the tolerant species in polluted sites. That is the case for other Chironomus species in our study that are present in all the sites, occupying selected oxygen-poor patches in non-polluted localities, and turning more ubiquitous in polluted sites. Wantzen et al. (2016) also found an association of Chironomus decorus group with low water quality and increased organic matter concentration, and Marques et al. (1999) suggested that only the genus Chironomus (and not the family or other groups) should be used as indicator of impacted sites.

A potential weakness of our methodology concerns the assignation of our gold standard for ROC analyses, but the categorization of studied sites into polluted and non-polluted have the support of previous assessments in the area (Domínguez and Fernández, 1998; Fernández et al., 2006) which provide DO, BOD and nutrient data for most of the sites. Additionally, the threshold used in our classification (site nonpolluted if less than two minor "impact categories" present), was 

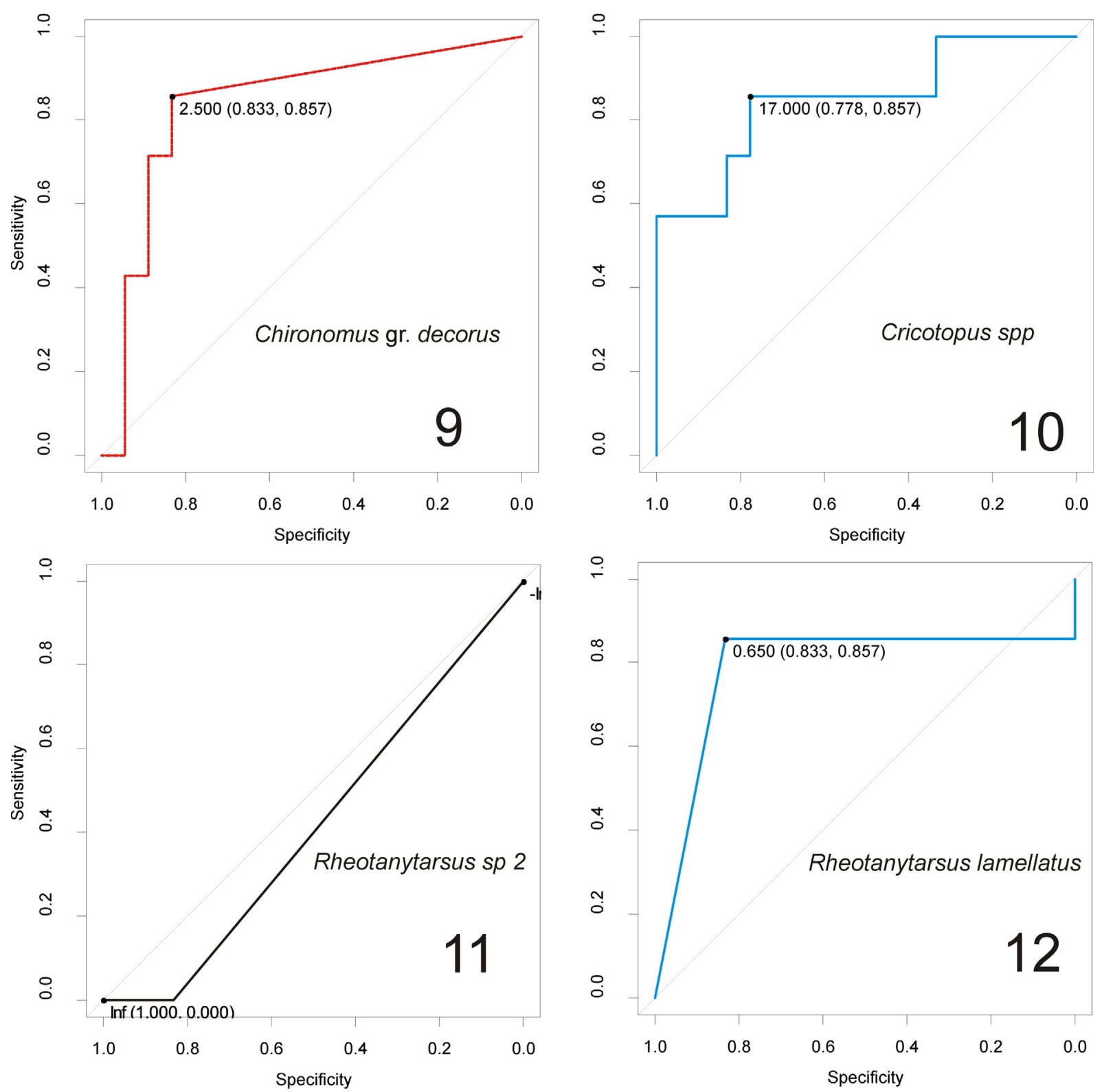

Figs. 9-12. ROC curves for some species or morpho-species (abundance data). 9, Chironomus gr. decorus ( $>2.5$ ind/m $\mathrm{m}^{2}$ indicate pollution); 10 , Cricotopus spp. ( $>17 \mathrm{ind} / \mathrm{m}^{2}$ indicate a healthy river); 11 , Rheotanytarsus sp. 2 (rare taxon, bad performance: below chance diagonal); $12, R$. lamellatus ( $>0.65$ ind $/ \mathrm{m}^{2}$ indicate healthy site).

validated in a broader study at family level (entire macroinvertebrate community from 95 sites, Dos Santos et al., 2011). Another major challenge of our study is the potential systematic natural environmental difference between the polluted and the non-polluted sites. In the studied region the non-polluted sites are smaller and higher-altitude streams compared to polluted ones. Thus the taxon-specific differences between the site groups would be caused by natural longitudinal impoverishment of Chironomidae assemblages along a river continuum. We have reduced this bias by including sites of varying altitude representing both conditions (polluted and non-polluted). Furthermore, the PCA ordination of the sites from physico-chemical variables did not discriminate both conditions, indicating that polluted and non-polluted sites are environmentally heterogeneous. Finally, Chironomidae assemblages from lower sites are known to be much more diverse in nonpolluted than in impacted streams in the region (Molineri et al., 2009; Romero et al., 2012).

\section{Conclusion}

The use of Chironomidae at the morpho-species level should be taken as a specialized monitoring tool since training in the use of identification keys and microscopic slide preparation is needed. Nevertheless, this relative difficulty is clearly overcome by the augmented discrimination capacity if compared with indices working at family or order levels. Furthermore, the use of these newly proposed metrics allows the monitoring of systems with communities composed almost exclusively by Chironomidae (e.g., frequently impacted by spates, high Andean sites, etc.).

The possibility to use generic richness of each subfamily or the entire family as an indicator is a methodological advantage: to recognize larval morpho-species or genera is easier than associating larvaadult for all the species (adults are needed for specific identification). Our results are opposite to Lenat (1983), who found that moderate pollution and sedimentation may increase richness of Chironomidae. If this increment exists, our data suggest a threshold (cut-off values) 
indicating impacted sites.

Our results and cut-off values can be directly extrapolated to other rivers of the Yungas ecoregion, including NW Argentina and Southern Bolivia. We also expect a correct performance in other Andean rivers, but cut-off values may prove to be higher or lower in more diverse or impoverished regions, respectively. We expect that this work encourage research on the tolerance of Chironomidae in areas where water bodies are dominated by this taxon and are increasingly affected by human impacts (e.g., Puna, the largest Lithium reserve shared by Chile, Argentina and Bolivia; Rodríguez Garay and Paggi, 2015; Nieto et al., 2016). Also we think that our analysis may contribute to the interpretation of paleolimnological data that use semi-fossilized Chironomidae larvae to reconstruct paleoenvironments (e.g., Howard et al., 2010).

\section{Author contributions}

All the authors equally contributed to acquisition, analysis and interpretation of data, and writing of manuscript.

\section{Acknowledgements}

We are grateful to Priscilla Powell and Karina García for sharing their samples for this study, to Daniel Dos Santos for the help with $\mathrm{R}$ scripts, and to the personnel of Instituto de Biodiversidad Neotropical that had taken and sorted some of the samples. Luciana de Cristobal kindly prepared the map shown in Fig. 1. CONICET PIP845 and PUE 099 partially financed this work. We acknowledge CONICET for constant support.

\section{Appendix A. Supplementary data}

Supplementary data to this article can be found online at https:// doi.org/10.1016/j.ecolind.2019.105703.

\section{References}

Armitage, P.D., Moss, D., Wright, J.F., Furse, M.T., 1983. The performance of a new biological water quality score system based on macroinvertebrates over a wide range of unpolluted running water sites. Water Res. 17, 333-347.

Bonada, N., Prat, N., Resh, V.H., Statzner, B., 2006. Developments in aquatic insect biomonitoring: a comparative analysis of recent approaches. Annu. Rev. Entomol. 52, 495-523.

Carter, J.L., Resh, V.H., Hannaford, M.J., 2017. Macroinvertebrates as biotic indicators of environmental quality. In: Methods in Stream Ecology, third ed. pp. 293-318.

Dos Santos, D.A., Molineri, C., Reynaga, M.C., Basualdo, C., 2011. Which index is the best to assess stream health? Ecol. Indic. 11, 582-589.

Domínguez, E., Fernández, H.R., 1998. Calidad de los ríos de la cuenca del Salí (Tucumán, Argentina) medida por un índice biótico. Conservación de la Naturaleza 12. Fundación Miguel Lillo, Tucumán.

Fernández, H.R., Domínguez, E., Romero, F., Cuezzo, M.G., 2006. La calidad del agua y la bioindicación en los ríos de montaña del Noroeste Argentino. Conservación de la Naturaleza 16. Fundación Miguel Lillo, Tucumán.

Heino, J., Melo, A.S., Siqueira, T., Soininen, J., Valanko, S., Bini, L.M., 2015. Metacommunity organization, spatial extent and dispersal in aquatic systems: patterns, processes and prospects. Freshwater Biol. 60 (5), 845-869.

Hilsenhoff, W.L., 1988. Rapid field Assessment of organic pollution with a family-level biotic index. J. North Am. Benthol. Soc. 7, 65-68.

Howard, L.C., Wood, P.J., Greenwood, M.T., Rendell, H.M., Brooks, S.J., Armitage, P.D.,
Extence, C.A., 2010. Sub-fossil Chironomidae as indicators of palaeoflow regimes: integration into the PalaeoLIFE flow index. J. Quatern. Sci. 25, 1270-1283.

Jacobsen, D., 1998. The effect of organic pollution on the macroinvertebrate fauna of Ecuadorian highland streams. Arch. Hydrobiol. 143, 179-195.

Kenkel, N.C., Orlóci, L., 1986. Applying metric and nonmetric multidimensional scaling to ecological studies: some new results. Ecology 67, 919-928.

Lasko, T.A., Bhagwat, J.G., Zou, K.H., Ohno-Machado, L., 2005. The use of receiver operating characteristic curves in biomedical informatics. J. Biomed. Inf. 38, 404-415.

Lenat, D.R., 1983. Chironomid taxa richness: natural variation and use in pollution assessment. Freshwater Invertebrate Biol. 2, 192-198.

Lenat, D.R., 1993. A biotic index for the southeastern United States: derivation and list of tolerance values, with criteria for assigning water-quality ratings. J. North Am. Benthol. Soc. 12, 279-290.

Lencioni, V., Marziali, L., Rossaro, B., 2012. Chironomids as bioindicators of environmental quality in mountain springs. Freshwater Sci. 31, 525-541.

Marques, M.M., Barbosa, F.A., Callisto, M., 1999. Distribution and abundance of Chironomidae (Diptera, Insecta) in an impacted watershed in south-east Brazil. Rev. Brasil. Biol. 59, 553-561.

Mendoza, E.A., González, J.A., 2011. Las ecorregiones del Noroeste Argentino: basadas en la clasificación climática de Köppen. Fundación Miguel Lillo.

Molineri, C., Romero, F., Fernández, H.R., 2009. Diversidad y Conservación de Invertebrados Acuáticos. In: Brown, A.D., Blendinger, P.G., Lomáscolo, T., García Bes, P. (Eds.), Selva Pedemontana de las yungas: historia natural, Ecología y Manejo de un ecosistema en peligro. Ediciones del Subtrópico, pp. 121-148.

Nicacio, G., Juen, L., 2015. Chironomids as indicators in freshwater ecosystems: an assessment of the literature. Insect Conserv. Divers. 8, 393-403.

Nieto, C., Malizia, A., Carilla, J., Izquierdo, A., Rodríguez, J., Cuello, S., Zannier, M., Grau, H.R., 2016. Patrones espaciales en comunidades de macroinvertebrados acuáticos de la Puna Argentina. Rev. Biol. Trop./Int. J. Trop. Biol. Conserv. 64, $747-762$.

Oksanen, J., Blanchet, F., Kindt, R., Legendre, P., Minchin, P., O’Hara, R., 2018. Vegan: Community Ecology Package. R Package Vegan, Vers. 2.2-1.

Paggi, A.C., 1999. Los Chironomidae como indicadores de calidad de ambientes dulceacuícolas. Rev. Soc. Entomol. Argentina 58, 202-207.

Paggi, A.C., 2003. Los Quironómidos (Diptera) y su empleo como bioindicadores. Biol. Acuática 21, 50-57.

Príncipe, R.E., Boccolini, M.F., Corigliano, M.C., 2008. Structure and spatial-temporal dynamics of Chironomidae Fauna (Diptera) in upland and lowland fluvial habitats of the Chocancharava River Basin (Argentina). Int. Rev. Hydrobiol. 93, 342-357.

Puntí, T., Rieradevall, M., Prat, N., 2009. Environmental factors, spatial variation, and specific requirements of Chironomidae in Mediterranean reference streams. J. North Am. Benthol. Soc. 28, 247-265.

Rabeni, C.F., Wang, N., 2001. Bioassessment of streams using macroinvertebrates: are the Chironomidae necessary? Environ. Monit. Assess. 71, 177-185.

Raunio, J., Paavola, R., Muotka, T., 2007. Effects of emergence phenology, taxa tolerances and taxonomic resolution on the use of the Chironomid Pupal Exuvial Technique in river biomonitoring. Freshwater Biol. 52, 165-176.

R Core Team, 2018. R: A Language and Environment for Statistical Computing. R Foundation for Statistical Computing, Vienna, Austria. https://www.R-project.org/.

Robin, X., Turck, N., Hainard, A., Tiberti, N., Lisacek, F., Sanchez, J.C., Müller, M., 2011. pROC: an open-source package for R and $\mathrm{S}+$ to analyze and compare ROC curves. BMC Bioinf. 12, 77.

Rodríguez Garay, G.N., Paggi, A.C., 2015. Chironomidae (Diptera) en cursos de agua de Puna y Chaco Serrano de Catamarca (Argentina): primeros registros y distribución de géneros y especies. Rev. Soc. Entomol. Argentina 74, 15-25.

Romero, F., Manzo, V., Fernández, H.R., Domínguez, E., Molineri, C., Nieto, C., Cuezzo, M.G., Abdala, V., Montero, R., 2012. Estudio integral de la cuenca del río Lules: aspectos biológicos. In: Barber, H., Fernández, H.R. (Eds.), En: La cuenca del río Lules. EDUNT, Tucumán, pp. 111-136.

Saether, O.A., 1979. Chironomid communities as water quality indicators. Ecography 2, 65-74.

Serra, S.R., Graça, M.A., Dolédec, S., Feio, M.J., 2017. Chironomidae traits and life history strategies as indicators of anthropogenic disturbance. Environ. Monit. Assess. 189, 326.

Tejerina, E.G., Malizia, A., 2011. Chironomidae (Diptera) larvae assemblages differ along an altitudinal gradient and temporal periods in a subtropical montane stream in Northwest Argentina. Hydrobiologia 686, 41-54.

Wantzen, K.M., Marchese, M.R., Marques, M.I., Battirola, L.D., 2016. Chapter 14: Invertebrates in Neotropical Floodplains. In: Batzer, D., Boix, D. (Eds.), Invertebrates in Freshwater Wetlands. Springer International Publishing Switzerland, pp. 493-524. 